\title{
TOKOH-TOKOH NATIVEPHILIA DALAM ANTOLOGI CERPEN SEMUA UNTUK HINDIA KARYA IKSAKA BANU: ANALISIS PASCAKOLONIAL HOMI K. BHABA
}

Nativephilia Characters in the Anthology of Short Stories Semua untuk Hindia by Iksaka Banu: Homi K. Bhaba Postcolonial Analysis

\section{Fadlun Suweleh}

Fakultas Ilmu Budaya, Universitas Gadjah Mada fadlunsuweleh1992@gmail.com

\begin{abstract}
Abstrak
Pada tahun 2014 antologi cerpen "Semua untuk Hindia" karya Iksaka Banu dinobatkan sebagai buku prosa terbaik oleh Kusala Sastra Khatulistiwa. Selain kelihaiannya memadukan fiksi dan sejarah, ada hal lain yang menarik dari antologi tersebut, yakni hadirnya tokoh-tokoh Eropa selaku narator atau tokoh sentral, namun tingkah laku mereka tak seperti orang Eropa pada umumnya. Mereka berpotensi memiliki keberpihakan (empati) pada Pribumi. Empati tokoh-tokoh Eropa tersebut bahkan menjadi konflik berulang. Pada penelitian ini, tokoh-tokoh Eropa yang berhaluan kepada Pribumi diistilahkan sebagai nativephilia. Dengan konsep split (terpecah / terbelah) yang dipopulerkan oleh Homi K. Bhabha, penelitian ini bertujuan untuk menguatkan pandangan Bhabha bahwa Timur (Pribumi) juga ternyata dapat membentuk Barat (Eropa) serta mengungkap bagaimana bentuk keterbelahan tokoh-tokoh nativephilia. Berdasarkan pengolahan data yang telah dilakukan, hasil dari penelitian ini menunjukkan bahwa tokoh-tokoh nativephilia tersebut menunjukkan keterbelahan yang bervariasi tatkala bersinggungan dengan Pribumi. Variasi tersebut yakni keterbelahan melalui verbal dan tindakan frontal. Kata-kata kunci: Nativephilia, Split, Pribumi, Poskolonial.
\end{abstract}

\begin{abstract}
In 2014, Iksaka Banu's anthology of short stories "Semua untuk Hindia" was named as the best prose book by Kusala Sastra Khatulistiwa (Khatulistiwa Literary Award). Apart from Banu's shrewdness in concocting fiction and history, there is another interesting thing from this anthology that the presence of European characters as narrators or central figures, but their behavior is unlike Europeans in general. They have the potential to take sides (empathy) with the Natives. The empathy of these European characters has even become a recurring conflict. In this study, European figures who leaned towards natives were termed nativephilia. With the split concept popularized by Homi K. Bhabha, this research aims to reinforces Bhabha's view that the East (Natives) can also form the West (Europe), and reveal what kind of division the nativephilia characters look like. Based on the data processing carried out, the results of this study indicate that the nativephilia characters show varying divisions when they interact with natives. The variation of this split is through verbal and frontal actions.
\end{abstract}

Keywords: Nativephilia, Natives, Postcolonial, Split.

How to Cite: Suweleh, Fadlun. (2020). Tokoh-Tokoh Nativephilia dalam Antologi Cerpen Semua Untuk Hindia Karya Iksaka Banu: Analisis Pascakolonial Homi K. Bhaba. Jentera: Jurnal Kajian Sastra, 9(2), 199-215. DOI : https://doi.org/10.26499/jentera.v9i2.2837 


\section{PENDAHULUAN}

Sastra sebagai media ekspresi tak pernah lepas dari segala sesuatu yang berkaitan dengan manusia dan peradaban, tak terkecuali dengan hal-hal yang berbau kolonial. Kajian poskolonial juga merupakan bagian dari jaringan sastra atas rekam jejak kolonialisme. Salah satu karya sastra yang mencoba menghadirkan kembali masa-masa kolonialisme di Indonesia adalah antologi cerpen "Semua untuk Hindia" karya Iksaka Banu. Antologi cerpen tersebut sangat kental dengan kenyataan sejarah bahwa Indonesia pernah menjadi bagian dari kolonialisme atau bangsa yang terjajah selama ratusan tahun. "Semua untuk Hindia" berisi tigabelas cerpen menarik yang diterbitkan pada tahun 2014. Kusala Sastra Khatulistiwa juga menobatkan buku ini sebagai buku prosa terbaik di 2014 (Heryanto, 2015).

Selain pilihan latar dan tema yang menarik, yakni sejarah Hindia Belanda di tanah air, kekuatan cerpen-cerpen Iksaka Banu justru pada tokoh-tokoh dalam cerita, permainan imaji, dan detail sejarah. Iksaka Banu mampu meramu ruang imaji di celah-celah fakta historis (Prasetyo Utomo, 2015), yakni memadukan fiksi dengan fakta-fakta sejarah. Ada kesamaan yang menarik dari ketigabelas cerpen dalam antologi "Semua untuk Hindia", yaitu empati para tokoh Eropa selaku narator kepada perjuangan dan keberanian pribumi untuk membebaskan diri dari kolonialisme (Prasetyo Utomo, 2015). Empati tersebut menjadi konflik yang selalu berulang dalam cerpen-cerpennya. Iksaka Banu menghadirkan banyak tokoh-tokoh Eropa selaku narator yang lebih condong pada tokoh pribumi dan bersimpati dengan kondisi Indonesia pada masa itu. Tokoh-tokoh Eropa yang menjadi fokus pengisahan senantiasa terbelah jiwanya, antara drinya yang Eropa (penjajah) atau dirinya yang bersimpati pada pribumi (terjajah). Tokoh-tokoh Eropa yang tingkah lakunya tak seperti orang Eropa secara umum tersebut berpotensi memiliki ketertarikan / empati / bahkan kasih sayang kepada pribumi. Pada penelitian ini, tokoh-tokoh Eropa yang berhaluan kepada pribumi tersebut diistilahkan sebagai nativephilia.

Istilah nativephilia pertama kali dipopulerkan oleh (Chotib, 2001). Dasar pembentukan istilah ini mengacu pada istilah sejenis yang terlebih dahulu baku, semisal anglophilia atau indianophilia. Sama seperti alasan Chotib, istilah ini semata-mata dimunculkan untuk penelitian ini dan tidak memiliki kepentingan lain. Sewaktu-waktu istilah ini dapat diganti bila telah atau nanti ada istilah yang lebih tepat (Wijaya, 2015: 5).

Berdasarkan latar belakang tersebut, fokus pembahasan dalam tulisan ini adalah mengungkap bagaimana bentuk keterbelahan tokoh-tokoh nativephilia dalam empat cerpen 
pada antologi "Semua untuk Hindia", dengan menggunakan konsep split yang ditawarkan oleh Homi K. Bhaba. Indikasi-indikasi penyimpangan mereka, yang sedang keluar dari kodrat Eropanya akan ditelusuri secermat mungkin. Penelitian ini juga menguatkan prediksi Bhabha terkait relasi subjektif antara penjajah dan terjajah, sehingga besar kemungkinan bahwa Timur (penjajah) juga dapat membentuk Barat (penjajah).

Penelitian terkait nativephilia pertama kali dilakukan oleh (Chotib, 2001) dalam tesisnya yang berjudul Analisis terhadap Tokoh-tokoh Nativephilia dalam Novel 'Reservation Blues' dan Novel 'Delia's Songs'. Dalam penelitannya Chotib menggunakan teori ideologi Louis Althusser dengan menekankan dua hal; subjek dan aparat ideologis, serta fokus pada satu tokoh dari masing-masing novel tersebut. Tujuan dari penelitian tersebut adalah untuk menunjukkan terbentuknya tokoh nativephilia dalam novel. Chotib juga menunjukkan peran ideologis seperti apa yang disembunyikan dari para tokoh nativephilia tersebut dan kaitannya dengan sistem ideologi kolonialisme.

Penelitian kedua ditulis oleh (Wijaya, 2015) dengan judul Representasi Pemikiran Pramoedya pada Tokoh-tokoh Nativephilia: Analisis Poskolonial Homi K. Bhabha pada Roman Tetralogi 'Pulau Buru' Karya Pramoedya Ananta Toer. Hasil dari penelitian ini menyatakan bahwa dua belas tokoh nativephilia di dalam roman tetralogi Pulau Buru dihadirkan sebagai representasi pemikiran Pramoedya. Melalui tokoh-tokoh nativephilia-nya, Pram relatif mempertahankan posisi dirinya sebagai Timur yang bijak. Pengalamannya sebagai bagian dari Hindia Belanda tidak membuatnya membenci Eropa (Barat) secara berlebihan. Pram mampu menakar Eropa dengan kalkulasi neraca yang seimbang.

Selain kedua penelitian tersebut, penelitian terkait antologi cerpen "Semua untuk Hindia" karya Iksaka Banu sebagai objek formal pernah dilakukan oleh (Mei Setyanigrum, 2015), dengan fokus pada dua cerpen. Pada penelitiaanya, penulis menjelaskan bentuk-bentuk representasi tokoh pribumi dan non-pribumi, resistensi para tokoh terhadap pemerintahan kolonialisme Belanda, serta relasi kuasa antar tokoh. Selanjutnya, beberapa ulasan dan tulisan tentang keunikan "Semua untuk Hindia" juga banyak dimuat di koran dan artikel. Seperti tulisan Joss Wibisono yang dimuat di TEMPO pada 6 Oktober 2014, Ariel Heryanto pada April 2015 di media-online IndoPROGRESS, dan lain-lain.

\section{LANDASAN TEORI}

Dalam suatu kuliah umum bertema Postcolonial Literature: The Example of the African Novel, (Aljayyar, 2018) mengatakan bahwa kolonialisme mengacu pada pendudukan atau 
penjajahan suatu negara atas negara lain, sedangkan pos-kolonialisme lebih mengacu pada efek yang ditimbulkan kolonialisme tersebut dalam berbagai aspek. Efek yang ditimbulkan menurut Bhabha tidak hanya dirasakan oleh kaum terjajah, namun juga penjajah. Kajian Homi Bhabha memprediksi 'relasi subjektif' yang ditimbulkan kolonialisme (Said, 2010: 531). Kajian tersebut menurut Said bisa menjadi salah satu kontribusi bagi pemahaman umum tentang jebakan-jebakan humanistik yang seringkali dimunculkan oleh sistem pemikiran terkait kolonial pada umumnya.

Bhabha dengan pemikirannya mengenai ruang ketiga, hibriditas, mimikri, dan ambivalensi mencoba mendobrak pemikiran-pemikiran Edward Said mengenai kolonialisme yang menurutnya terlalu kaku (Epafras, 2012). Relasi subjektif yang dimaksud Bhabha adalah kondisi dan relasi antara si penjajah (Barat; atau Eropa, dalam konteks penelitian ini) dan si terjajah (Timur; Pribumi) tidak selalu harus beroposisi biner. Kelenturan identitas yang tercipta dalam relasi Eropa dan Pribumi inilah yang dipotret oleh Bhaba (Kusumaningrum, 2019, p. 54).

Selanjutnya, Bhabha dalam esainya menyinggung konsep split. Dalam konteks ini, split dapat diartikan sebagai terbelah atau terpecah. Tidak hanya Timur yang mengalami keterbelahan, Barat pun menurut Bhabha sangat mungkin mengalami keterbelahan saat bersinggungan dengan Pribumi. Di sinilah istilah nativephilia digunakan.

Untuk mengetahui detail istilah nativephilia, Chotib memberi keterangan sebagai berikut.

Diartikan secara harfiah, dua kata yang membentuk istilah nativephilia memang berarti "orang-orang yang mencintai para Pribumi". "orang-orang" dan "para Pribumi" sebagai subjek dan objek dalam artian istilah nativephilia tersebut. Dalam konteks istilah nativephilia beserta segala artian yang telah dijelaskan, kata "mencintai" akan lebih tepat apabila diterjemahkan dalam lingkup pengertian kata "keberpihakan". Bahwa para nativephilia ini "berpihak, membela, atau cenderung cocok" dengan para Pribumi (Chotib, 2001: 5).

Dari keterangan tersebut dapat disimpulkan bahwa, orang-orang nativephilia memiliki atensi positif terhadap pribumi, dan perhatian mereka tersebut ditunjukkan secara frontal baik antara sadar maupun tidak sadar. Mereka keluar dari jalur ke-Eropaan atau jalur kolonial mereka karena berbagai sebab. Keterbelahan (split) orang-orang Eropa tersebut menyebabkan 'penyimpangan' dan menjadikan mereka nativephilia.

Menurut (Bhabha, 2007, p. 66), hal penting dari wacana kolonial adalah ketergantungannya pada konsep ‘percampuran' dalam konstruksi ideologi keliyanan. Percampuran sebagai tanda perbedaan budaya, kesejarahan, rasial dalam diskursus kolonial. Salah satu bentuk benturan ideologis tersebut terwujud melalui kehadiran tokoh-tokoh 
nativephilia dalam teks. Selain itu Bhabha menyatakan bahwa timbal balik peradaban niscaya akan terjadi.

Pertemuan kedua lapisan masyarakat tersebut telah lama terbentuk selama berabad-abad sehingga adanya keunggulan monolit atau monoton dari satu pihak akan terus-menerus mengalami perubahan atau pergeseran. Menjurus kepada pembuktian bahwa tokoh Eropa juga dapat menganggap Pribumi sebagai kaum yang baik dan positif, bahkan dapat pula melebihi posisi dan kondisi tokoh Eropa itu. Timur ternyata dapat membentuk Barat melalui teori yang diutarakan oleh Bhabha. Eropa memang berpeluang ditemukan sedang tidak berada dalam keEropa-an asli mereka di dalam wacana Poskolonial, tetapi sedang menjadi Eropa yang sedang mengalami ketertarikan terhadap Pribumi (Wijaya, 2015: 8).

Bhabha menjelaskan bahwa baik pihak penjajah dan pihak terjajah tidak independen satu sama lain. Hubungan-hubungan kolonial itu distrukturkan oleh bentuk kepercayaan yang sangat kontradiktif dan beraneka ragam. Menurut Bhabha, antara penjajah dan terjajah terdapat ruang ketiga, yaitu ruang yang memungkinkan keduanya berinteraksi. Di ruang inilah kaum terjajah menemukan strategi perlawanan terhadap dominasi wacana penjajah. Bukan melawan dengan cara frontal, melainkan justru dengan perselingkuhan atau adaptasi budaya, yaitu dengan mengambil alih tanda-tanda budaya penjajah, tapi diberi isi dan digugat sehingga menghasilkan identitas dan cara hidup yang baru. Namun pada kasus nativephilia, yang terjadi adalah sebaliknya, yakni penjajah memiliki respek kepada pribumi dan segala sesuatu yang berkaitan dengan bangsa terjajah. Bagi Bhabha, ruang ketiga justru bisa menjadi transformasi budaya yang diciptakan dari hubungan keduanya (penjajah dan terjajah). Hal yang pasti adalah produk budaya menimbulkan persoalan baru karena sangat bertendensi menimbulkan dan menunjukkan ambivalensi, hati yang mendua, dan hal tersebut berlaku bagi pihak terjajah (Pribumi) maupun pihak penjajah (Eropa).

Untuk memahami tokoh-tokoh nativephilia salah satunya adalah dengan menempatkan pihak Eropa menjadi subjek yang mengalami keterbelahan atas keberadaannya. Subjek kolonial (Eropa) yang berada pada suatu kondisi dapat menjadi terbelah. Ketika ia menempati satu sisi dirinya yang lain, ia juga tidak serta merta meninggalkan sisi lainnya (Bhabha, 2007: 142). Subjek kolonial tersebut mengalami keterbelahan sebab berhubungan dengan bayangan gelapnya sendiri (dalam konteks ini Pribumi bisa dimaksudkan sebagai bayang gelap) yang mempengaruhi dirinya. Keadaan tersebut yang menyebabkan subjek kolonial rela untuk membagi dirinya demi keadaan lain (Wijaya, 2015: 18). 
Dengan demikian, prediksi Bhabha terkait relasi subjektif antara penjajah dan terjajah bisa diasumsikan benar adanya. Karena faktanya tidak hanya dunia Barat yang bisa mengimajinasikan ataupun membentuk karakter dunia Timur. Sebaliknya, dalam wacana Poskolonial Timur pun mampu membentuk Barat. Karena tidak hanya ada relasi dominasi dalam wacana tersebut, namun juga interaksi antara penjajah dan terjajah.

\section{METODE PENELITIAN}

Menurut Faruk, metode penelitian merupakan cara untuk memperoleh pengetahuan mengenai suatu objek, sehingga harus sesuai dengan kodrat keberadaan objek itu sebagaimana yang dinyatakan oleh teori (Faruk, 2012: 55). Dalam penelitian ini dilakukan dua tahapan penelitian, yakni pengumpulan data dan analisis data. Adapun data yang dimaksud dalam penelitian ini adalah satuan tekstual yang berhubungan dengan teori poskolonial yang dikembangkan oleh Homi K, Bhaba dengan fokus pada konsep split. Data dapat dibedakan menjadi dua, yakni data primer dan data sekunder. Data primer terdiri atas beberapa paragraf yang diperoleh dari cerpen "Semua untuk Hindia" yang berhubungan dengan konsep poskolonial. Kemudian, data sekunder merupakan teks historis, sosial, dan kultural yang mendukung, yang berhubungan dengan cerpen.

Ada dua tahapan yang dilakukan dalam penelitian ini, yakni pengumpulan data dan analisis data. Metode dan teknik pengumpulan data ini pada dasarnya adalah seperangkat cara atau teknik yang merupakan perpanjangan dari indra manusia karena tujuannya adalah mengumpulkan fakta-fakta empirik yang terkait dengan masalah penelitian (Faruk, 2012, p. 25). Langkah pengumpulan data diawali dengan pembacaan berulang terhadap objek material, yakni antologi "Semua untuk Hindia" karya (Banu, 2014). Kemudian, pengelompokan data disesuaikan dengan landasan teori serta fokus penelitian. Selain dari novel, data dikumpulkan dari jurnal, buku-buku, dan artikel atau tulisan lain yang berhubungan dengan objek material.

Langkah terakhir adalah analisis data. Menurut Faruk, analisis data merupakan seperangkat cara atau teknik penelitian yang merupakan perpanjangan dari pikiran manusia karena fungsinya bukan untuk mengumpulkan data, melainkan untuk mencari hubungan antardata yang tidak akan pernah dinyatakan sendiri oleh data yang bersangkutan (Faruk, 2012: 25). Berikutnya, variabel yang ditemukan dalam proses pengumpulan data akan dicari hubungannya satu sama lain sehingga menjadi satu kesatuan (Jati, 2020: 33). Berdasarkan latar belakang masalah yang telah diidentifikasi, analisis dalam penelitian ini dilakukan untuk 
menelaah keterbelahan jati diri pada tokoh-tokoh nativephilia yang memilih antara berpihak kepada Pribumi (Timur) atau kepada Eropa (Barat).

\section{PEMBAHASAN}

Bhabha membuktikan bahwa wacana kolonial selalu bersifat ambigu, polisemik. Karena itu, konstruksi kolonial mengenai mengenai dirinya maupun mengenai Timur dapat memperoleh pemaknaan yang bermacam-macam dan bahkan bertentangan (Faruk, 2007: 6). Adapun beberapa tindakan para tokoh nativephilia yang diduga condong pada Pribumi, dapat dikatakan sebagai polisemik dari wacana kolonial tersebut. Beberapa tokoh tersebut memperlihatkan ketertarikan dan keberpihakan mereka melalui tindakan frontal, dan beberapa lainnya melalui verbal, seperti ungkapan pujian, dan sebagainya.

\section{Maria Geertruida Weleillend (Geertje), dalam Cerpen "Selamat Tinggal Hindia"}

Tokoh pertama yang memiliki beberapa ciri dan tindakan yang condong pada Pribumi adalah Maria Geertruida Weleillend atau Geertje. Ia merupakan gadis Belanda totok, namun lahir dan besar di Hindia Belanda. Melalui tokoh Belanda lain yakni Martinus Witkerk selaku narator dalam cerpen, Iksaka Banu mendeskripsikan keberpihakan Geertje kepada pribumi dengan sangat detil. Pertemuan pertama Geertje dan Martin adalah saat Geertje berjalan menenteng koper bukan menuju rombongan truk yang akan ke Bandung, melainkan ke jalan lain, bersiap memilih becak, menuju Gunung Sahari. Dalam percakapan pertama kedua tokoh tersebut, sudah terlihat bahwa Geertje lebih memilih tetap tinggal bersama para Pribumi, daripada mengikuti pengungsi kulit putih lainnya yang tengah menuju Kapel Ursulin.

\footnotetext{
"Aku tidak ikut," Geertje menatapku tajam. "Truk-truk ini menuju Bandung. Ke tempat penampungan di Kapel Ursulin. Sebagian lagi ke Tanjung Priok. Aku harus pulang ke Gunung Sahari. Banyak yang harus kukerjakan." Katanya.

"Maksudmu, sebelum Jepang dating, engkau tinggal di Gunung Sahari, dan sekarang hendak kembali ke sana?" tanyaku.

"Ada yang salah?" Geertje balik bertanya.

"Ya. Salah waktu dan tempat. Pembunuhan terhadap kulit putih, Tionghoa, dan orang-orang yang dianggap kolaborator Belanda semakin menjadi. Mengapa ke sana?" tanyaku.

“Karena itu rumahku. Permisi," Geertje membalikkan badan. (Banu, 2014: 6)
}

Sikap Geertje lainnya yang secara terang-terangan menunjukkan keberpihakkannya terhadap Pribumi adalah, kebanggaannya menggunakan atribut yang sudah menjadi salah satu khas daerah Pribumi, yakni terompah atau sejenis alas kaki dari kayu. Meski dalam beberapa sumber diungkapkan bahwa bakiak atau terompah kayu bukan atribut asli Pribumi, melainkan peninggalan dari Jepang, sumber lainnya menjelaskan bakiak berasal dari Tionghoa (Dwi 
Cahyono, 2020), namun bakiak tetap bukan bagian dari Eropa dan masih melekat dengan budaya Jawa maupun Sumatra.

\footnotetext{
"Apakah kau tak ingin membuang bakiak kamp itu?" tanyaku sambil melirik kaki Geertje. "Bukankah para tantara di sana menyediakan sepatu untuk wanita dan anak-anak? Mereka juga membagikan gincu dan bedak. Kalian akan kembali rupawan."

"Belum terbiasa bersepatu lagi, jadi kusimpan di koper. Di kamp, aku mahir berlari dengan bakiak," Geertje tertawa, meletekkan tubuhnya ke jok belakang. (Banu, 2014: 6)
}

Dalam kutipan di atas Martin menawarkan Geertje untuk mengganti bakiaknya dengan sepatu. Beberapa sumber menyatakan bahwa sepatu pertama kali ditemukan di Missouri (Amerika Serikat), di Prancis, dan di Yunani Kuno dengan rentan waktu yang berbeda-beda. Sepatu juga dipopulerkan oleh orang-orang Eropa terlebih dahulu. Hal tersebut membuktikan bahwa sepatu bukan bagian dari identitas Pribumi. Martin merasa penampilan Geertje dengan fisiknya yang Belanda totok akan lebih pantas dengan sepatu, bukan dengan bakiak.

Bentuk nativephilia lain yang ditunjukkan Geertje adalah mahirnya ia mendendangkan lagu rakyat Sulawesi Utara 'Si Patokaan' saat kembali ke rumah lamanya di Gunung Sahari. Geertje menemukan piano yang telah lama ia tinggalkan, lalu dengan santai ia menyanyikan lagu rakyat tersebut yang kemudian ditimpali Martin dengan sedikit heran. Pasalnya, nyaris tak ada warga totok Belanda yang mau bersusah payah menghafal nada dan lirik lagu rakyat Pribumi.

Geertje meniup debu tipis, membuka penutup tuts. Sepotong irama riang menjelajahi ruangan.

"Lagu rakyat?" tanyaku.

"Si Patoka'an." Geertje mengangguk, lalu bersenandung menimpali ketukan tuts.

"Engkau menyatu dengan alam dan penduduk di sini. Mereka juga menyukaimu. Mungkin mencintaimu setulus hati," kataku. (Banu, 2014: 8)

Selain melalui tindakan secara frontal, Geertje juga menunjukkan atensinya kepada Pribumi secara verbal. Bagaimana ia lebih menganggap Hindia Belanda sebagai bumi pertiwinya. Ia juga mengungkapkan bahwa dirinya enggan mengikuti beberapa warga totok lain yang akan kembali ke negeri asal mereka. Geertje mengaku tak tertarik kembali ke Belanda dengan alasan ia tidak yakin apakah ia masih memiliki rumah untuk ditinggali di Belanda nanti. Meski Martin sudah menawarkan rumah dan tempat tinggal di salah satu desa di Belanda serta beberapa kali mengajak Geertje kembali ke Belanda, tawaran-tawaran tersebut tetap ditolak oleh Geertje dengan berbagai alasan.

“...Aku sendiri seorang guru sekolah pribumi. Lahir, besar di tengah para pribumi. Saat Jepang berkuasa, kusadari bahwa Hindia Belanda bersama segala keningratannya telah usai. Aku harus berani mengucapkan selamat tinggal kepadanya. Dan apapun yang ada di ujung nasib, aku akan tetap tinggal di sini. Bukan sebagai 'penguasa', seperti istilahmu. Entah sebagai apa...." 
"Kita ada di tengah pergolakan besar dunia. Nilai-nilai bergeser. Setelah berabad, kita menyadari tanah ini bukan Ibu Pertiwi kita," jawabku. "Untuk ketigakalinya kuminta, pergilah selagi bisa." (Banu, 2014: 9-10)

Sebagai tokoh nativephilia, kebimbangan tentu dirasakan oleh Geertje. Meski dirinya tak ragu memilih untuk tetap tinggal di Hindia Belanda, namun ia masih mempertanyakan identitasnya 'entah sebagai apa' kelak. Ia menolak dikatakan sebagai penguasa seperti orangorang Eropa lainnya. Namun ia juga tidak bisa menjadi Pribumi seutuhnya karena tak hanya nama, fisiknya pun Belanda totok.

Pada kasus yang sangat umum, sebagaimana yang dijelaskan Bhabha dalam (Faruk, 2007: 6), tindakan terjajah yang meniru penjajah bisa disebut sebagai mockery atau ejekan. Karena sebenarnya mereka tidak sepenuhnya meniru ataupun setia dengan model yang ditawarkan penjajah. Namun pada kasus Geertje adalah sebaliknya, saat ia menggunakan bakiak, menyanyikan lagu Si Patokaan, dia benar-benar sedang meniru Pribumi bukan sebagai ejekan melainkan karena atensinya kepada Pribumi. Hal tersebut dapat diasumsikan sebagai bentuk polisemik dari wacana kolonial yang disebutkan oleh Bhabha. Keterbelahan Geertje mencakup verbal dan juga tindakan frontal.

\section{Fred Goretti Aachenbach dalam Cerpen "Racun untuk Tuan"}

Tokoh kedua yang menunjukkan empati dan keberpihakannya pada Pribumi adalah seorang pegawai swasta Eropa, Fred Goretti Aachenbach. Fred dipindahtugaskan untuk mengurus perkebunan tembakau terpencil di Deli, Hindia Belanda. Seperti lelaki Eropa kebanyakan, awalnya Fred menikahi Imah hanya sebagai Nyai atau istri sementara tuan berkulit putih selama mereka bertugas Hindia Belanda. Namun seiring berjalannya waktu, Imah yang sangat piawai dalam mengurus rumah tangga, Imah yang pengertian terhadap Fred, bahkan Imah telah melahirkan dua anak Fred, membuat Fred mulai merasa ketergantungan terhadap Imah.

BERANDA BERBENTUK SETENGAH lingkaran, dan perempuan kecil di hadapanku. Sudah ratusan kali aku duduk di beranda ini bersamanya. Biasanya mulai pukul lima, sepulangku bekerja. Persis seperti saat ini. la akan datang dengan kopi serta kudapan dalam stoples. Lalu kami bercakap sedikit tentang peristiwa hari itu, atau sekadar termangu menatap kaki bukit, memerhatikan galur-galur ladang tembakau yang tampak seperti permukaan kasur berwarna hijau tua. Pemandangan luar biasa yang tak pernah kujumpai di tanah kelahiranku...

Itulah sebagian besar hariku bersamanya, sebelum semua hal kembali surut seperti awal kedatangannya di rumah ini. Jauh, asing, bahkan lebih parah lagi: hampa... (Banu, 2014: 37)

Keterbelahan Fred mulai ia rasakan saat kembali ke tanah kelahirannya di Spijkenisse (Belanda), di sana ia bertemu teman wanita semasa kecilnya Helena Huberta Theunis. 
Selanjutnya atas dukungan kedua pihak keluarga, Fred memutuskan untuk menikahi gadis Eropa tersebut.

Sudah menjadi rahasia umum di masa penjajahan status para Nyai tak diakui namun hidupnya dieksploitasi. Seperti yang dikutip Reegie Baay dalam tulisan 'Nyai dan Pergundikan di Hindia Belanda' (Bataviaach Nieuwsblad, 1898), lelaki Eropa tak ingin mengakui Nyai mereka karena dianggap nista, namun di sisi lain mereka juga merasa diuntungkan karena dengan memiliki Nyai, mereka tak perlu repot mendatangkan perempuan Eropa, juga tak perlu mengkhawatirkan penyakit kelamin dari rumah-rumah bordil (Janti, 2018).

Demikian pula yang terjadi, sekembalinya Fred dari Spijkenisse, Fred dengan segala kegamangannya terpaksa memilih mengusir Imah dan kedua darah daginya secara halus, karena istri Eropanya Helena akan segera menyusul dirinya ke Hindia Belanda. Fred menyarankan Imah dan anak-anaknya untuk sering berkunjung, ia juga menawarkan pakaian-pakaian untuk dibawa Imah. Di sisi lain meskipun Fred mengusir Imah, Fred masih sempat mempersoalkan peraturan Eropa terkait warna pakaian seorang Nyai pribumi sebagai simbol status. Meski hanya suara hatinya yang protes, namun hal tersebut sudah menjadi bukti keberpihakan / kecintaannya terhadap Pribumi. Dia yang Eropa, merasa tidak adil dengan peraturan warna pakaian yang dianggapnya tidak menghormati Pribumi.

\footnotetext{
Sesungguhnya telah kuminta ia membawa seluruh kebaya putihnya. Aku tak mau istri Eropaku kelak melihat tumpukan kain itu di dalam lemari. Tapi ia menolak. Takut dianggap menyalahgunakan simbol status, yang kini tak lagi di sandangnya. Pernyataan itu ibarat tamparan keras di wajah. Membuatku berpikir, siapa pecundang gila hormat yang dulu membuat peraturan aneh bahwa seorang Nyai harus bisa dibedakan secara kasat mata lewat warna bajunya?

Mengapa sehelai kebaya-dan maksudku memang benar-benar kain kebaya-yang berwarna putih memiliki nilai lebih dibandingkan warna lain? Apakah karena dianggap paling dekat dengan warna kulit orang Eropa? (Banu, 2014: 38)
}

Bentuk nativephilia lain dalam diri Fred adalah saat ia menyadari bahwa selama ini ternyata dirinya tak pernah memanggil nama Belanda Imah. Hal tersebut secara tidak langsung menjadi bukti bahwa Fred sejak awal memang menerima Imah apa adanya sebagai Pribumi, tak seperti lelaki Eropa kebanyakan yang biasanya akan memaksa, mengajari, dan memoles istri Pribuminya menjadi seperti wanita-wanita Eropa.

"Imah," aku berhenti sebentar seolah baru sadar, selama ini aku tak pernah memanggil nama Belandanya. Ya, kurasa nama yang ia ucapkan saat tiba pertama kali dulu memang lebih cocok untuknya dibandingkan Maria Goretti Aachenbach. (Banu, 2014: 38)

...Pada saat yang sama, ada semacam tekanan keras meng impit dadaku. Membuat kedua kakiku goyah. Aku tahu, ini perasaan yang biasa berkecamuk manakala kita menya dari akan kehilangan orang yang kita sayangi selamanya. Perasaan yang dahulu juga hadir saat liang lahat ayah tercinta mulai di timbuni tanah. (Banu, 2014: 46) 
Puncak dari nativephilia yang dialami Fred bukan saat dirinya yang hampa setelah mengusir Imah dan menyadari betapa pentingnya Imah bagi hidupnya. Namun keputusan dan tindakan terakhir yang Fred lakukan saat mengetahui hidangan terakhir yang disiapkan Imah untuk dirinya adalah hidangan yang dengan sengaja dicampuri pil nomor 11 oleh Imah, sebagai upaya terakhir Imah membalaskan dendam dan rasa sakitnya karena telah dicampakkan.

Pil nomor 11 biasanya berisi larutan phenyl, arsenik, atau air liur ular kobra, yang dulu konon sering digunakan para Nyai untuk membunuh suami (Tuan berkulit putih) yang telah mencampakkan atau menyakiti dirinya (Banu, 2014: 47). Dan Fred tau akan hal itu, namun rasa sayang, kehilangan, bersalah, dan sederet perasaan lainnya membuat Fred lebih memilih mati di tangan Pribumi yang sudah mengisi hari-harinya.

Kutimang sekali lagi gelas di tanganku. Lantas kureguk habis isinya.
(Banu, 2014: 48)

Tindakan Fred mengusir Imah dapat diasumsikan sebagai usaha untuk mempertahankan ke-Eropa-annya. Sedangkan keputusan Fred untuk meneguk gelas yang berisi racun tersebut adalah puncak kecintaannya kepada Imah yang merupakan Pribumi. Hal ini selaras dengan yang diungkapkan (Bhabha, 2007: 106-107), bahwa pemujaan selalu merupakan permainan atau kebimbangan antara penegasan yang kuno perihal keutuhan / kesamaan, dengan kecemasan yang berkaitan dengan kekurangan dan perbedaan. Kebimbangan Fred untuk mempertahankan status dirinya yang Eropa atau cintanya pada Imah yang Pribumi, menjadi bukti bahwa dirinya sebagai subjek kolonial mengalami keterbelahan. Keterbelahannya mencakup verbal sekaligus tindakan frontal.

\section{Bastiaan De Wit, dalam Cerpen "Semua untuk Hindia"}

Tokoh selanjutnya yang menunjukkan bentuk nativephilia-nya terhadap Pribumi secara dengan tindakan frontal adalah Bastiaan De Wit, seorang wartawan Belanda yang tulus mengagumi gadis Bali bernama Tabik. Bastiaan bahkan sudah menganggap Tabik seperti adik kecilnya. Seperti Tabik dan kebanyakan Pribumi pada umumnya yang berpikir bahwa perang sama sekali bukan hal yang baik, Bastiaan juga berpikir perang baginya tak lain hanya perusak kesetiaan dan kasih sayang.

Tuang Lange adalah pedagang Belanda yang kerap ke Puri. Fasih berbahasa Bali... kusimpulkan ia berada satu biduk denganku: Biduk para penentang arus yang berusaha mengembalikan harta dan martabat bumiputra yang telah kami isap tanpa malu selama tiga ratus tahun. (Banu, 2014: 62) 
Bastiaan mengakui bahwa negara asalnya adalah parasit bagi Hindia Belanda. Dengan kedok memberadabkan namun sejatinya menyengsarakan negri yang indah tersebut. Dalam beberapa narasi ia juga sangat menyayangkan dan sama sekali tidak mendukung sikap petinggipetinggi Belanda yang memperlakukan petinggi Pribumi secara semena-mena. Kekagumannya dengan adat dan budaya Bali, membuatnya mempertanyakan kebenaran keberadaan para penjajah, orang-orang Eropa, termasuk dirinya, yang datang ke negeri kaya rempah tersebut dengan dalih membawa peradaban modern.

Adik kecil. Dua bulan di Puri membuatku jatuh cinta pada semua hidangan yang kau masak. Dan melihatmu berlatih menari, menyatukan diri dengan alam, adalah anugerah yang tak putus kusyukuri hingga kini. Membuatku kembali tersudut dalam tanda tanya besar: Benarkah kehadiran kami di sini, atas nama pembawa peradaban modern, diperlukan? (Banu, 2014: 62)

Pada akhir cerita, Baastian yang juga ikut dalam perang sebagai pihak penjajah, ia begitu kacau dan panik lantaran tak sanggup membayangkan para Pribumi, terutama adik kecilnya Tabik, menjadi korban kebengisan bangsanya sendiri. Ia mengalami keterbelahan yang sangat luar biasa. Di satu sisi ia tak bisa mengabaikan tugasnya sebagai wartawan Belanda peliput perang De Locomotief. Namun di sisi lain ia juga tidak rela dengan kebrutalan negaranya sendiri terhadap rakyat Bali yang begitu ia kagumi.

Ya, tadi siang aku ikut mendobrak Puri. Bukan dengan kegembiraan seorang penakluk, melainkan kecemasan seorang sahabat. Harus kupastikan, tak ada prajurit yang berani meletakkan jari di atas tubuhmu. (Banu, 2014: 64)

Di scene berikutnya Baastian tak dapat menahan emosinya saat ia menemukan tubuh adik kecilnya Tabik, yang tak lama lagi akan menjadi mayat. Ia juga balik menghantam dan menyerang tantara Belanda yang membunuh Tabik, menjadi bukti tindakan frontal dia terhadap negaranya sendiri demi membela salah satu Pribumi yang disayanginya.

\footnotetext{
“Uang kepeng! la melemparku dengan uang kepeng dan kau tembak kepalanya! Pembunuh?”

"Cukup!" sesuatu menghantam tengkukku. Aku terkapar.

"Beginilah kalua wartawan ikut perang," samar-samar kulihat Jenderal Rost van Tonningen menyarungkan pistolnya seraya memandang sekeliling sebelum kembali menatapku.

"Berhentilah menulis hal buruk tentang kami, Nak. Aku dan tentaraku tahu persis apa yan sedang kami lakukan. "Semua untuk Hindia". Bagaimana denganmu? Apa panggilan jiwamu?"

Aku tidak menjawab.

(Banu, 2014: 71)
}

Puputan dalam bahasa Bali berarti 'mati' atau 'habis', dengan kata lain puputan berarti bertempur melawan musuh hingga titik darah penghabisan. Dalam peristiwa Puputan di Bali 20 september 1906, Raja Badung memerintahkan seorang imam untuk menusuk dirinya, 
tindakan tersebut lalu diikuti oleh seluruh rakyat Bali. Mereka saling menikam satu sama lain hingga tewas (Creese, 2006). Bunuh diri menjadi bentuk perlawanan terakhir rakyat Bali.

Dalam bukunya Indische Reisherinneringen, H.M van Weede juga memuat kejadian penting Puputan Badung. Pada peristiwa Puputan, sejumlah besar wanita sengaja melempar uang kepeng atau perhiasan sebagai tanda pembayaran bagi sedadu Belanda yang bersedia mencabut nyawa mereka Beberapa perempuan melempar mata uang emas kepada pasukan penjajah sebagai balasan jasa atas pembunuhan mereka. Mereka menunjuk-nunjuk pada jantung mereka bermaksud ingin dibunuh. Para perempuan heroik melempar uang kepeng sebagai tanda bahwa mereka menyambut kematian dengan sukacita, serta tak memiliki hutang piutang dengan para tentara yang menembak mereka (Walhi Bali, 2015).

Hal tersebut pula yang terjadi pada Tabik di hadapan Bastiaan. Kematian Tabik menjadi titik balik keberpihakkan Bastiaan kepada Hindia Belanda dan Pribumi. Bastiaan mengalami keterbelahan antara dirinya sebagai wartawan Belanda, dengan dirinya sebagai kakak angkat salah satu Pribumi. Sejak awal, proses pembelahan Bastiaan tidak sekedar terlihat bahwa dia ingin menolak atau menghilangkan jati dirinya yang Eropa, namun juga terlihat bahwa dia menemukan kenyataan lain yang berbeda mengenai Pribumi. Kenyataan tersebut yang menjadi keyakinan pada diri Bastiaan sehingga ia condong pada Pribumi.

\section{Jorijs Handlanger dalam Cerpen "Penunjuk Jalan"}

Pada tokoh terakhir dalam analisis ini tidak begitu menampakkan nativephilianya terhadap Pribumi secara frontal, melainkan hanya melalui verbal, seperti ungkapan-ungkapan kekaguman dan pujian terhadap salah satu tokoh Pribumi. Jorijs Handlanger merupakan seorang dokter asal Belanda yang mengalami kesialan saat pertama kali menginjakkan kakinya di Hindia Belanda. Dalam cerpen tersebut, kebersamaan dokter yang sangat singkat dengan sekelompok Pribumi dan seorang pemimpin kelompok yang ia panggil Pangeran, begitu membekas di hari sang dokter.

Bagi Jorijs, Pangeran (dalam narasi dijelaskan bahwa Pangeran yang dimaksud Jorijs adalah Untung Suropati, salah seorang tokoh dalam sejarah Nusantara) adalah seorang Pribumi yang berbudi luhur dan mulia. Ungkapan-ungkapan kekaguman dan pujian dituturkan langsung oleh dokter dalam cerpen.

"Apa yang Anda lakukan? la bisa lumpuh," kurenggut tangan si tabib seraya memaki dalam bahasa Melayu. Kutumpahkan pula amarahku kepada Pangeran. la diam, tapi mendadak jarinya mematuk bahuku, membuat lenganku gontai. 
Tokoh-Tokoh Nativephilia dalam Antologi.....

“Anda harus percaya kepada Kyai Ebun," kata Pangeran.
“Telah ratusan kali ia melakukan pengobatan semacam ini. Memang sakit. Tapi lihat hasilnya."
"Pengobatan?" kutatap wajah-wajah dalam ruangan itu. Gila, aku seorang sarjana. Penjaga nyala api
Prometheus. Penerus sumpah Hippocrates. Mati kutu di hadapan para duta dari lorong tergelap ilmu
pengetahuan.

Keesokan harinya, kujenguk Joep. Wajahnya pucat, tapi matanya mulai bersinar.

"Aku merasa lebih sehat, Heer Doctor," bisiknya. Kuraba kakinya yang dibebat. Tulang-tulang pecah itu tak bertonjolan lagi. Bagaimana mereka melakukannya?

“Orang Belanda mengobati sakit dari luar. Kami membiarkan tubuh menyembuhkannya dari dalam," Pangeran berdiri di belakangku dengan dua gelas kopi panas.

(Banu, 2014: 125)

Di awal percakapan terlihat bahwa Jorijs memandang remeh Pribumi yang menurutnya adalah orang-orang dari peradaban terbelakang. Ia merasa superior dengan statusnya Eropa yang dirasa lebih tinggi dari Pribumi. Namun pada hari berikutnya ia justru kagum dengan cara pengobatan salah seorang Kyai Pribumi, meski baginya kejadian tersebut juga sedikit menurunkan derajat seorang Jorijs Handlanger sebagai sarjana dokter. Jorijs juga kagum dengan kegesitan dan kelincahan Pribumi yang ia temui di tenda pengungsian.

Kuperiksa situasi perkemahan. Seluruh penghuninya sibuk berkemas. Sejumlah tenda sudah dibongkar. Ternak di kumpulkan dan puluhan gerobak telah rapi dibariskan. Sungguh, orang-orang ini bekerja dengan kecepatan mengagumkan. (Banu, 2014: 125-126)

Bentuk nativephilia lain yang ditampakkan oleh sang dokter adalah saat ia akhirnya mengetahui jati diri asli seorang yang ia panggil Pangeran, ternyata adalah ketua penyamun yang menjadi buronan tantara Belanda. Ketertarikan dan kekagumannya bukan memudar lantaran kabar yang ia dengar dari teman Eropanya, sebaliknya, ia justru menaruh respek yang dalam kepada Pangeran.

Kuamati lebih dekat. Tiba-tiba aku tersentak. Di sana, di belakang Cornelia. Dilukis dalam nuansa hijau kecokelatan. Seorang pemuda berambut panjang memanggul payung militer di bahu kanan, sementara tangan kirinya dengan jenaka mengutil jeruk yang dibawa seorang budak wanita.

“Mijn God! Tak salah!" aku nyaris histeris. "Sang Pangeran."

"Betapa berwarna hidupnya," entah mengapa, aku tersenyum geli. "Bagaimana keluarga Cnoll memanggil namanya?"

"Oentoeng atau semacam itu. Entahlah, ia seorang budak," Vuijborn mengangkat bahu. "Kau bisa memanggilnya siapa saja."

"Ya, tentu saja," aku menghela napas panjang. Kusimak lagi sosok kecil dalam lukisan itu. Sepasang alis yang kuat, mata yang tajam, dan segelas kopi panas tadi pagi.

Tiba-tiba aku merasa kesepian. (Banu, 2014: 127-129)

Di akhir kutipan Jorijs mengaku kesepian, hal tersebut memberikan penafsiran bahwa seakan Untung Suropati yang disebutnya Pangeran melengkapi dirinya yang kosong. Tak peduli ia adalah Pribumi atau ketua penyamun dan juga buronan orang-orang dari negaranya 
sendiri. Ketika sang Eropa mengalami transformasi dan diidentifikasi sedang berpihak atau condong kepada Pribumi, maka keberpihakannya tidak akan pernah utuh atau sempurna. Pertentangan di dalam batinnya akan selalu membuatnya tidak absolut untuk berdiri pada titik lain di seberangnya. Ia merasa lebih namun sekaligus merasa kurang (Wijaya, 2015: 16). Demikan pula yang terjadi pada Jorijs. Ketika ia melebihkan dirinya untuk Pangeran, maka ia merasa kekurangan pada dirinya sendiri. Inilah yang disebut sebagai titik pengingkaran yang membuatnya menjadi nativephilia.

Selain keempat tokoh nativephilia yang telah dijelaskan tersebut, masih ada beberapa tokoh lainnya yang memiliki antensi lebih pada Pribumi dalam antologi cerpen "Semua untuk Hindia”. Seperti tokoh Matthijs Adeelar van Rijk dalam cerpen Stambul Dua Pedang, yang menjadi budak cinta istri Pribuminya, Sarni. Matthjis dengan segala kekuasaannya sebagai lakilaki Eropa, bisa saja menghukum Sarni yang bermain api dengan lelaki Pribumi lainnya. Namun kecintaannya terhadap Sarni membuat dirinya bersusah payah mengembalikan kehormatan pernikahannya. Tindakannya tersebut merupakan puncak dari kecintaannya kepada Sarni, dan menjadi bukti bahwa ia layak dikategorikan menjadi tokoh nativephilia. Ada juga kekaguman mendalam Letnan Phillipe Lecroix kepada Pangeran Diponegoro, yang juga diamini oleh Letnan Antoinne Pascale Renanrd selaku narator dalam cerpen Pollux.

Beberapa tokoh dalam antologi cerpen "Semua untuk Hindia" yang menampilkan bentuk-bentuk nativephilia mereka dengan berbagai cara yang tentu tak lepas dari kelihaian Iksaka Banu dalam meramu alur di setiap cerita. Iksaka bahkan mampu mengemas dan membuat sterotipe baru bahwa tak semua bangsa penjajah memperlakukan Pribumi sama seperti yang ada dalam sejarah. Beberapa dari mereka yang sudah cukup lama di negeri jajahan, memahami dan mengenal langsung kondisi Pribumi juga mampu 'terwarnai' atau 'terkontaminasi' oleh bangsa jajahannya. Hal tersebut juga menguatkan pandangan Bhabha terkait wacana kolonial bahwasannya, tak hanya Barat yang dapat membentuk Timur, sebaliknya, Timur juga dapat membentuk atau mempengaruhi Barat. Hal tersebut karena tak hanya dominasi, namun juga ada interaksi antara penjajah dan terjajah (Barat dan Timur).

(Setiawan, 2011) menyebut interaksi tersebut dengan istilah 'keberantaraan kultural'. Keberantaraan kultural lebih disebabkan oleh kontestasi narasi yang berlangsung dalam ruang kultural. Kontestasi inilah yang menjadikan cara pandang masyarakat tidak bisa dikatakan utuh; masyarakat sebagai subjek menjadi terpecah (Setiawan, 2011: 129). Dalam hal ini Eropa bisa dikontekskan sebagai masyarakat / subjek yang terpecah, seperti pada keempat tokoh tersebut. 


\section{SIMPULAN}

Dalam antologi cerpen "Semua untuk Hindia", Iksaka Banu menghadirkan empat tokoh nativephilia yang secara terang-terangan menunjukkan ketertarikan dan keberpihakan mereka kepada Pribumi. Dari analisis yang telah dilakukan dapat disimpulkan bahwa tokoh-tokoh tersebut mengalami keterbelahan antara menunjukkan keadaannya yang asli dengan keadaannya yang lain. Mereka menunjukkan keragaman keterbelahan yang bervariasi tatkala bersinggungan dengan Pribumi. Varian tersebut yakni keterbelahan melalui verbal dan keterbelahan melalui tindakan frontal.

Melalui cerpen-cerpennya Iksaka Banu yang menghadirkan tokoh-tokoh nativephilia ini dapat juga menguatkan prediksi Bhabha terkait relasi subjektif antara penjajah dan terjajah dalam wacana poskolonial. Sehingga benar bahwa Eropa (Barat) juga dapat dibentuk atau terkontaminasi oleh Pribumi (Timur). Geertje, Fred, Bastiaan, dan Jorijs yang merupakan tokoh nativephilia dalam antologi cerpen tersebut menunjukkan bahwa Eropa tidak selalu menempati atau direfleksikan sebagai Eropa itu sendiri, namun mereka dapat direfleksikan sebagai Eropa yang lain, yakni Eropa yang ke-Pribumian. Eropa dapat membelenggu Pribumi juga sekaligus membebaskan Pribumi. Di sinilah konsep split yang dikemukakan oleh Homi K. Bhabha itu terjadi.

\section{DAFTAR PUSTAKA}

Aljayyar, S. (2018). Postcolonial Literature: The Example of the African Novel. Postcolonial Literature: The Example of the African Novel.

Banu, I. (2014). Semua untuk Hindia. Kepustakaan Populer Gramedia. https://lakonhidup.com/2018/04/07/teh-dan-pengkhianat/

Bhabha, H. K. (2007). The location of culture. In The Location of Culture. London dan New York: Routledge Classics. https://doi.org/10.4324/9780203820551

Bukan Belanda Kolonial. (2014). https://majalah.tempo.co/read/buku/146443/bukan-belandakolonial

Creese, H. (2006). Seabad Puputan Badung: perspektif Belanda dan Bali (H. Creese (ed.)). KITLV Jakarta, Universitas Udayana, Pustaka Larasan.

Chotib, M. N. (2001). Analisis terhadap tokoh-tokoh Nativephilia dalam Novel Reservation Blues dan Novel Delia's Song. 
Dwi Cahyono, M. (2020). Theklek, Alas Kaki Lintas Masa: Jejak Terompah Purba Masa Majapahit. https://nusadaily.com/essay/theklek-alas-kaki-lintas-masa-jejak-terompahpurba-masa-majapahit.html

Epafras, L. C. (2012). Signifikansi pemikiran Homi Bhabha. November 2012, 1-8.

Faruk. (2007). Belenggu pasca-kolonial : hegemoni dan resistensi dalam sastra Indonesia. Pustaka Pelajar.

Faruk. (2012). Metode Penelitian Sastra: Sebuah Penjelajahan Awal. In Pustaka Pelajar.

Heryanto, A. (2015). Indonesia dalam Indo: Menghargai Semua Untuk Hindia «Indoprogress. 2015(April 2015), 1-12.

Janti, N. (2018). Nyai Tak Pernah Diakui. https://historia.id/politik/articles/nyai-tak-pernahdiakui-PRylA/page/1

Jati, G. P. (2020). Transmisi Memori dan Wacana Rekonsiliasi dalam Cerpen "Perempuan Sinting Di Dapur" Karya Ugoran Prasad: Kajian Postmemory. JENTERA: Jurnal Kajian Sastra, 9(1), 28. https://doi.org/10.26499/jentera.v9i1.2265

Kusumaningrum, A. F. (2019). Krisis Identitas Dalam Cerpen a Pair of Jeans Karya Qaisra Shahraz. Jurnal POETIKA, 7(1), 51-62. https://doi.org/10.22146/poetika.43500

Mei Setyanigrum, P. (2015). Representasi, Relasi Kuasa, Dan Resistensi Dalam Cerpen "Semua Untuk Hindia” Dan "Selamat Tinggal Hindia” Karya Iksaka Banu: Analisis Psikoanalisa.

Prasetyo Utomo, S. (2015). Fantasi dalam Narasi Historis. https://republika.co.id/berita/n192vx/fantasi-dalam-narasi-historis

Said, E. W. (2010). Orientalisme: Menggugat Hegemoni Barat dan Mendudukkan Timur sebagai Subjek. Yogyakarta Pustaka Pelajar.

Setiawan, I. (2011). Modernity, Locality, and Postcoloniality of Villagers In The 80s. LITERASI: Indonesian Journal of Humanities.

Tragedi Puputan Badung: Bunuh diri massal rakyat Bali tahun 1906. (2019). https://www.brilio.net/creator/tragedi-puputan-badung-bunuh-diri-massal-rakyat-balitahun-1906-757f25.html

Wibisono, J. (2014). Bukan Belanda Kolonial. https://majalah.tempo.co/read/buku/146443/bukan-belanda-kolonial

Wijaya, G. S. (2015). Representasi Pemikiran Pramoedya pada Tokoh-tokoh Nativephilia, Analisis Pascakolonial Homi K. Bhabha, Pada Roman Tetralogi Pulau Buru Karya Pramoedya Ananta Toer. 